\section{Российские внешние активы и обязательства: пора собирать камни}

А.В. АЛЕКСЕЕВ, кандидат экономических наук,

Н.П. ДЕМЕНТЬЕВ, доктор физико-математических наук,

Институт экономики и организации промышленного производства СО РАН,

Новосибирск. E-mail: avale@mail.ru

В статье рассматриваются динамика ввоза и вывоза капитала в РФ, основные направления и эффективность его инвестирования. Демонстрируется экономическая неоправданность вывода значительнх финансовых ресурсов за рубеж. Доказывается наличие в РФ серьезных финансовых ресурсов, достаточных не только для эффективного противодействия западным санкциям, но и для существенного ускорения национального экономического развития. Ключевые слова: вывоз капитала, ввоз капитала, прямые инвестиции, чистая международная инвестиционная позиция, активы, обязательства

В общественно-политическом дискурсе все чаще звучат алармистские нотки: источники финансирования для российского бизнеса закрываются, присутствие на внешних рынках осложняется, капитал, столь необходимый для структурной перестройки экономики в условиях санкций, уходит из страны. Насколько эти опасения обоснованны? Так ли в действительности жестки финансовые ограничения развития российской экономики?

\section{Вывоз капитала}

Основания для беспокойства как будто действительно есть. Так, вывоз капитала частным сектором из РФ в 2014 г. достиг 153 млрд долл., а инвестиции в основной капитал составили 13,5 трлн руб. [1], или 356,3 млрд долл. по среднему номинальному курсу доллара США к рублю с начала года. Если бы весь вывезенный капитал остался в России, то отечественную инвестиционную программу теоретически можно было бы увеличить почти в 1,5 раза. Это серьезно.

Не стоит думать, что масштабный вывоз капитала из РФ в 2014 г. - исключительное явление. За последние 16 лет чистый ввоз капитала наблюдался лишь дважды (в 2006-2007 гг.), причем в небольших масштабах. В благополучном 2013 г. чистый вывоз капитала был в 2,5 раза меньше, чем в 2014 г., когда были объявлены западные санкции. Предыдущий пик вывоза капитала также пришелся на кризисный 2008 г. (133,6 млрд долл.). Просматривается ожидаемая закономерность: чем лучше обстоят дела в российской экономике, тем менее интенсивно капитал уходит из нее, а при ухудшении - капитал бежит. Заметное снижение чистого вывоза капитала в 2015 г. (а в третьем квартале даже его чистый ввоз - впервые со второго квартала 2010 г.), очевидно, признак если и не явного улучшения ситуации в российской экономике, то точно ее стабилизации.

Всего с 2000 г. по 2014 г. из РФ было выведено почти 0,5 трлн (493,1 млрд долл.). С учетом предварительных данных за 2000-2015 гг. вывоз капитала составил 565,3 млрд долл. (рис. 1)

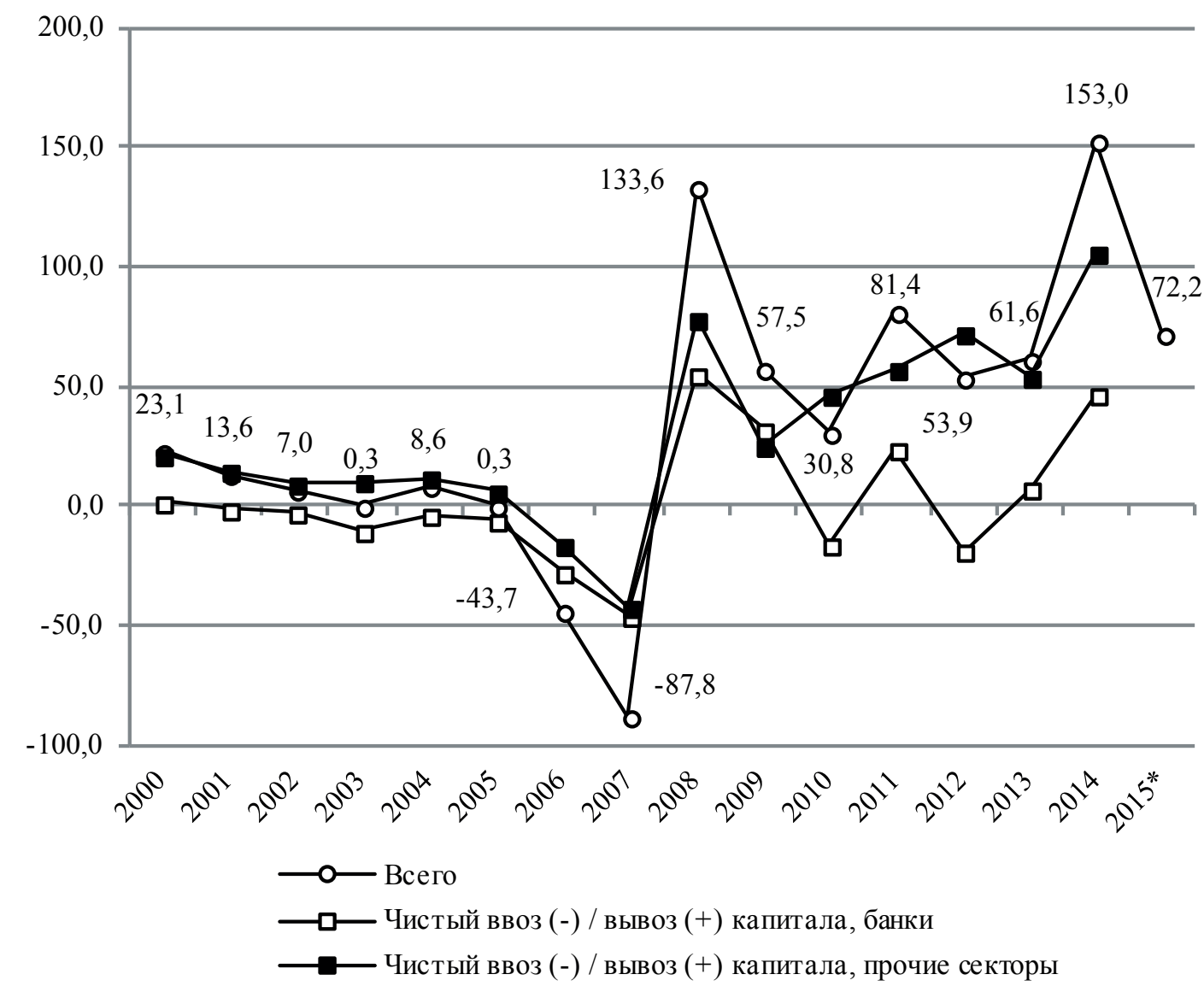

* Оценка. Минфин ожидает возобновления оттока капитала из РФ в IV квартале. PИA Новости. URL: http://ria.ru/economy/20151009/1299460071.html Источник рис. 1-4, табл. 2: ЦБ РФ. Статистика внешнего сектора. URL: http:// www.cbr.ru/statistics/? Prtld=svs (дата обращения: 05.10.2015).

Рис. 1. Чистый ввоз/вывоз капитала частным сектором в 2000-2015 гг., млрд долл. 
Согласно счету текущих операций, сальдо экспорта и импорта российских товаров, услуг, полученных и выплаченных первичных и вторичных доходов с 2000 г. всегда было положительным (рис. 2). Это означает, что с 2000 г. по 2015 г. ${ }^{1}$ в РФ пришло чуть более 1 трлн долл.

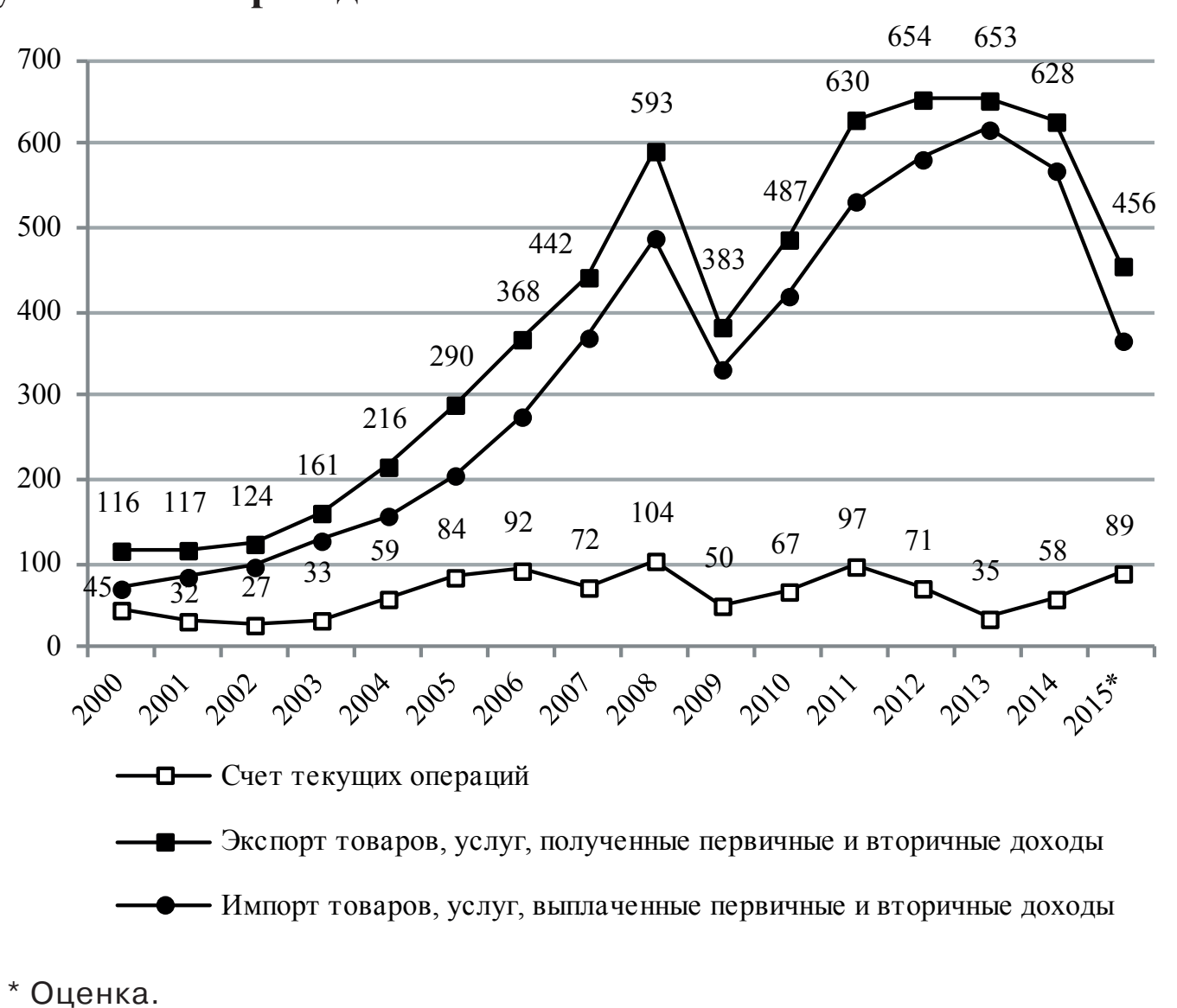

Рис. 2. Платежный баланс Российской Федерации в 2001-2015 гг., млрд долл.

С учетом счета операций с капиталом (на протяжении рассмотренного периода он почти всегда отрицательный) финансовый счет оказался меньше - примерно 800 млрд долл. Разница в 200 млрд долл. со счетом текущих операций определилась двумя составляющими. Во-первых, Россия, как известно, «щедрая душа»: за рассматриваемые 16 лет она простила долгов своим партнерам почти на 93 млрд долл. Понятно, что это невозвратные долги еще советского периода, тем не менее с баланса они в последние годы постепенно списываются. Примерно 80 млрд долл. - это чистые ошибки и пропуски, или, выражаясь менее дипломатичным языком, незаконный вывод валюты за рубеж. Формально, с учетом рассмотренных двух крупных статей (безвозвратных потерь для российской экономики), чистое кредитование остального мира составило около 800 млрд долл.

Однако подобный «бухгалтерский» подход оставляет чувство некоторой недосказанности. «Процентные» долги явно формировались еще в прошлом веке, да и в величине списания наверняка учтены проценты по этим долгам. Мы же рассматриваем динамику счета текущих операций с 2000 г. Формально 93 млрд долл. списаны со счета пришедшего в РФ 1 трлн долл. но «физически» они никуда не делись.

Не вполне понятна и ситуация с «чистыми пропусками и ошибками». Если эти деньги потеряны для РФ в терминах платежного баланса, то из этого вовсе не следует, что они пропали для отдельных российских резидентов. Не все они пошли на потребление; какая-то их часть вполне может быть материализована в виде российских активов за рубежом.

\section{Российские активы за рубежом}

Вывезенный капитал использовался на приобретение активов за рубежом. За рассматриваемый период эти активы не просто существенно выросли (с 249 млрд долл. на конец 2000 г. до 1,251 трлн долл. на начало 2015 г.), они увеличились именно на 1 трлн долл., т. е. практически в точности на величину счета текущих операций платежного баланса РФ за рассматриваемый период (табл. 1).

Прямое сопоставление этих двух величин не вполне корректно, так как российские зарубежные активы, с одной стороны, росли вследствие прямых операций, а с другой - сокращались из-за переоценки и прочих изменений. Так, за рассмотренный период активы выросли на 1,5 трлн долл. в результате операций, но одновременно и сократились на 198 млрд долл. вследствие их переоценок и еще на 300 млрд долл. - прочих операций.

Каждая из этих цифр по-своему интересна. Так, согласно счету текущих операций, РФ располагала 1 трлн долл., а зарубежные активы в результате операций увеличились на 1,5 трлн долл. «Недостающие» 0,5 трлн долл. - очевидно, заемные средства привлеченные российскими резидентами за рубежом. Таким образом, российский бизнес не только склонен к выводу капитала за границу, но идет дальше - активно привлекает 
капитал на мировом рынке для приобретения активов, но не в национальной юрисдикции, а вне ее.

Таблица 1. Международная инвестиционная позиция Российской Федерации

\begin{tabular}{|c|c|c|c|c|c|}
\hline \multirow[b]{2}{*}{ Показатель } & \multirow[b]{2}{*}{$\begin{array}{c}\text { Остаток на } \\
01.01 .2001\end{array}$} & \multicolumn{3}{|c|}{ Изменения: } & \multirow[b]{2}{*}{$\begin{array}{l}\text { Остаток на } \\
01.01 .2015\end{array}$} \\
\hline & & $\begin{array}{c}\text { в ре- } \\
\text { зультате } \\
\text { операций }\end{array}$ & $\begin{array}{c}\text { в ре- } \\
\text { зультате } \\
\text { пере- } \\
\text { оценки }\end{array}$ & прочие & \\
\hline $\begin{array}{l}\text { Чистая международная инвестиционная } \\
\text { позиция }\end{array}$ & 64545 & 707318 & -116635 & -350994 & 304234 \\
\hline Активы & 248752 & 1500987 & -198433 & -300210 & 1251096 \\
\hline Прямые инвестиции & 20141 & 532381 & -219053 & 55136 & 388605 \\
\hline Портфельные инвестиции & 1268 & 84080 & -20485 & -8231 & 56632 \\
\hline \begin{tabular}{|l|} 
Производные финансовые инструменты (кроме \\
резервов) и опционы на акции для работников
\end{tabular} & 0 & -92755 & 110204 & 117 & 17565 \\
\hline Прочие инвестиции & 199371 & 654014 & -70847 & -379702 & 402836 \\
\hline Резервные активы & 27972 & 323267 & 1748 & 32471 & 385458 \\
\hline Обязательства & 184207 & 793669 & -81798 & 50785 & 946863 \\
\hline Прямые инвестиции & 32204 & 490904 & -200625 & 31744 & 354227 \\
\hline Портфельные инвестиции & 32132 & 4175 & 53876 & 66367 & 156550 \\
\hline $\begin{array}{l}\text { Производные финансовые инструменты (кроме } \\
\text { резервов) и опционы на акции для работников }\end{array}$ & 0 & -107066 & 128101 & 495 & 21530 \\
\hline Прочие инвестиции & 119871 & 405747 & -63150 & -47822 & 414646 \\
\hline
\end{tabular}

Рассчитано по: ЦБ РФ. Статистика внешнего сектора. URL: http://www.cbr.ru/ statistics/? Prtid=svs\&ch=Par_47562\#Checkedltem (дата обращения: 09.10.2015).

Тому, что в мире становится все больше активов, подконтрольных резидентам РФ, можно было бы только радоваться, но специфика «бизнеса по-русски» за рубежом озадачивает. Казалось бы, вложенные деньги должны приумножаться. Но Россия, как обычно, идет своим путем - деньги тают. За 15 лет было инвестировано 1,5 трлн долл., а к концу рассматриваемого срока остался только 1 трлн. Полтриллиона (одна треть!) растворились в переоценках и прочих изменениях.

Прочие изменения. С ними российскому бизнесу особенно «не везет»: на них за рассматриваемый период было потеряно 300 млрд долл. (годовой объем российских инвестиций в основной капитал). Отметим, что в решающей степени «прочие изменения» формируются статьей «прочая дебиторская задолженность».

С последовательностью, достойной лучшего применения, российский бизнес ее формирует, а потом практически полностью списывает. Например, в 2013 г. в результате операций сформировалась дебиторская задолженность в размере 33 млрд долл. Из них 27 млрд долл. было списано. Удивительная щедрость! 2014-й - тяжелый санкционный год. Величина дебиторской задолженности здесь меньше - 14,4 млрд долл. Казалось бы, в условиях резкого ухудшения условий внешнего финансирования необходимо бороться за каждый доллар. Но - нет! В этом году зарубежным контрагентам было прощено 10,9 млрд долл. (а еще на 2,3 млрд долл. дебиторская задолженность была переоценена, естественно, в сторону уменьшения).

В решающей степени дебиторская задолженность формируется в «прочих секторах», но этому явлению не чужда и банковская сфера. Все становится на свои места, если вспомнить, что до 2005 г. ныне «политкорректное» название статьи «прочая дебиторская задолженность» звучало по-другому: «своевременно не полученная экспортная выручка, не поступившие товары и услуги в счет переводов денежных средств по импортным контрактам, переводы по фиктивным операциям с ценными бумагами». Проще говоря - незаконный вывод валюты за рубеж.

Прочая дебиторская задолженность (говоря эзоповым языком ЦБ) очень быстро росла до 2008 г. (почти в девять раз за семь лет) (рис. 3). В последующие годы ее динамика весьма неустойчива, но лишь в 2014 г. масштабы явления, которое ЦБ не называет воровством, существенно сократились. Время покажет, случайный это выброс или действительно смена вех.

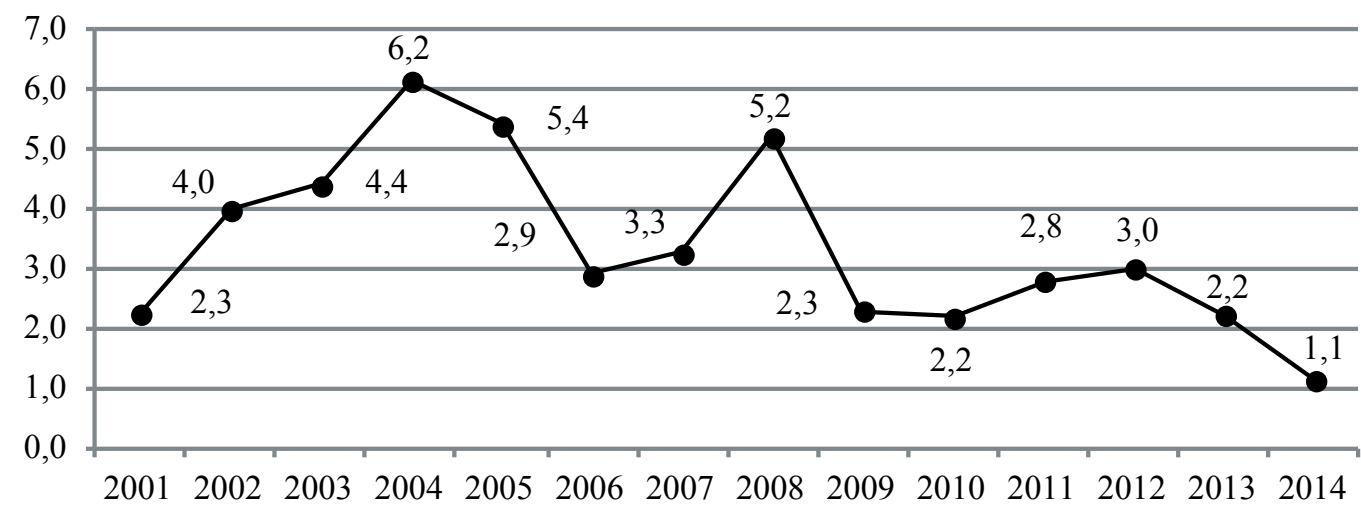

Рис. 3. Прочая дебиторская задолженность в активах РФ в 2001-2014 гг., млрд долл.

Переоценка активов. Не везет российскому бизнесу и с динамикой стоимости приобретенных активов. Качественный актив 
характеризуется тем, что во времени его цена имеет тенденцию к росту (хотя бы из-за инфляции). До 2008 г. стоимость российских активов за рубежом по результатам ежегодных переоценок действительно увеличивалась. Кризисное обесценение активов в 2008 г. от этого прироста оставило немного, но ситуация как будто стала выправляться в 2009-2010 гг. В 2011 г. происходит резкое обесценение активов, затем отскок в 2012 г., вновь заметное падение в 2013 г. и почти столь же катастрофическое обесценение активов в 2014 г., как в 2008 г. (рис. 4). Результат: с 2001 по 2014 гг. российские активы потеряли почти 200 млрд долл. своей стоимости. Правда, если смотреть период 2001-2013 гг., то вывод был бы противоположный - российские активы были бы в выигрыше.

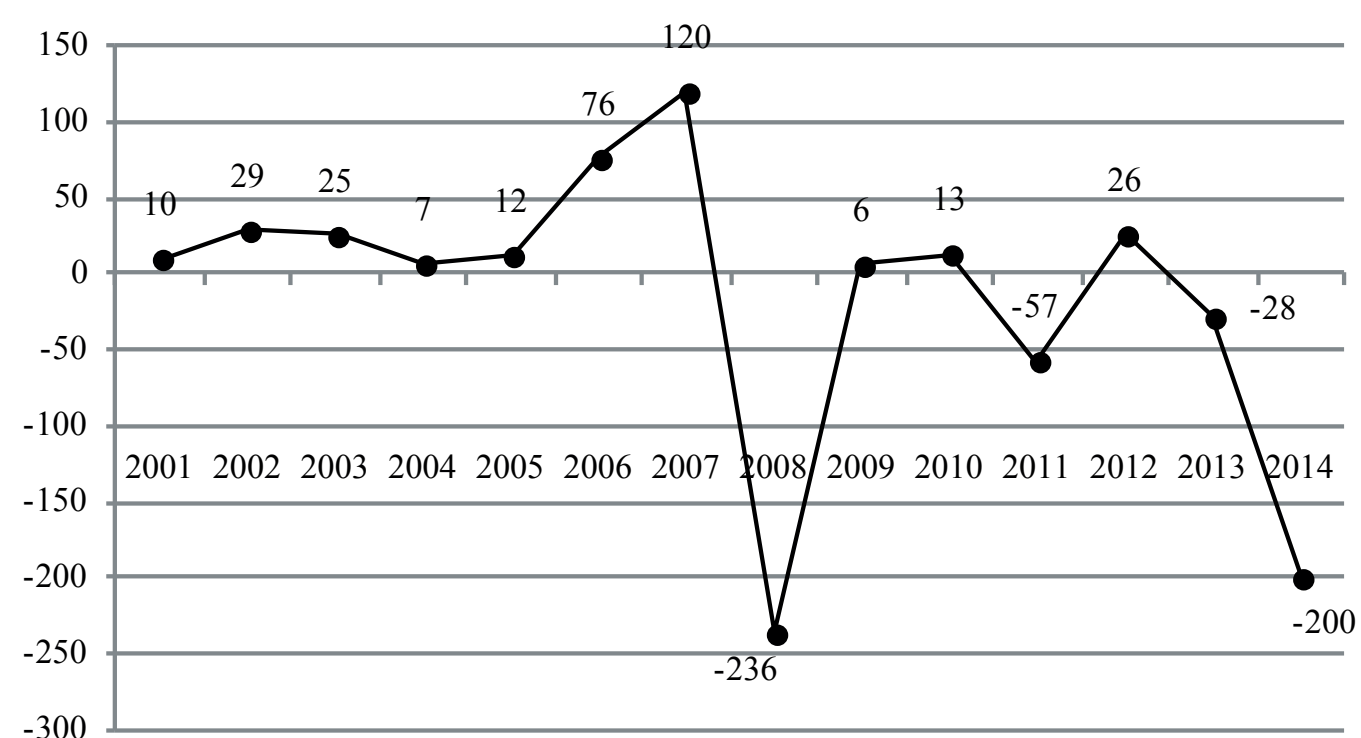

Рис. 4. Изменение стоимости

зарубежных активов РФ в результате

переоценки в 2001-2014 гг., млрд долл.

Отчасти эти потери объективны - мировой финансовоэкономический кризис 2008-2009 гг. так или иначе отразился на стоимости всех активов. Тем не менее в 2002-2003 гг., когда, например, индекс S\&P 500 быстро падал, стоимость российских зарубежных активов продолжала расти, а в 2013-2014 гг., когда он стремительно рос, стоимость российских активов, напротив, катастрофически сокращалась (рис. 5). Отметим, что в совокупном обесценении российских активов 2014 г. примерно три четверти пришлись на прямые инвестиции.

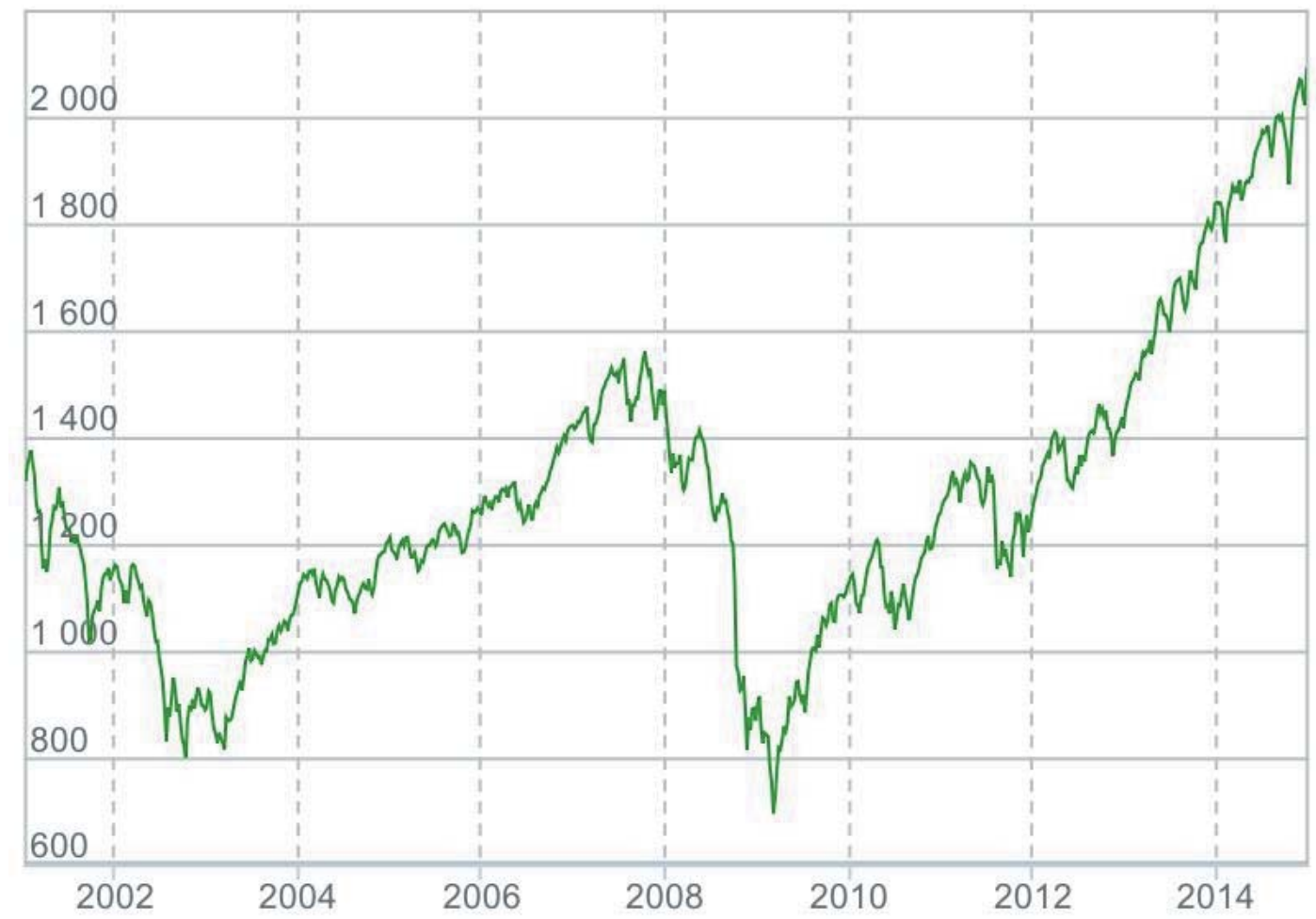

Источник: URL: http://world.investfunds.ru/indicator/view/222/?datefrom=01.01.2 000\&dateto=16.11.2015 (дата обращения: 16.11.2015).

Рис. 5. Динамика индекса S\&P 500 в 2002-2014 гг.

Прямые инвестиции. Российские зарубежные активы состоят из трех сопоставимых по величинам частей - прямых (участие в капитале и акции инвестиционных фондов: 388,4 млрд долл. на начало 2015 г.) и портфельных инвестиций (56,6 млрд долл.), прочих инвестиций (наличная валюта и депозиты - 181,3 млрд долл., а также ссуды и займы 166,8 млрд долл.) и резервных активов (385,5 млрд долл., в том числе: монетарное золото - 46,1 млрд долл., наличная валюта и депозиты - 42,3 млрд долл., долговые ценные бумаги - 285,5 млрд долл.)

Не стоит забывать, что в статистике ЦБ внешний сектор представлен в долларах, а значительная часть российских активов за рубежом номинирована в других валютах (главным образом в евро). Евро же в течение 2014 г. по отношению к доллару заметно упал (с 0,728 Euro на 01.01.2014 г. до 0,826 Euro на 31.12.2014 г.). Но такое изменение курса все же не объясняет 145-миллиардное обесценение российских прямых инвестиций при общей их величине в 479,5 млрд долл. на начало 2014 г. 
Рассмотренное обесценение российских зарубежных активов в 2014 г. дает основание выдвинуть весьма неприятную для характеристики российских зарубежных прямых инвестиций гипотезу. По умолчанию представляется, что российские прямые инвестиции за рубежом - это «вложения денежных средств в материальное производство и сбыт с целью участия в управлении предприятием» [2] за рубежом. Поэтому девальвация или, наоборот, ревальвация рубля не должны сказываться на их долларовой оценке.

Но здесь нюанс! Российские компании переводят значительные средства в свои зарубежные офшорные компаниидочки, которые проходят в статистике как прямые инвестиции из России. Однако большую часть полученных средств дочки инвестируют в российскую же экономику путем крупных покупок акций отечественных компаний (материнских большей частью). Поскольку дочки находятся под юрисдикцией страны-офшора, то такие покупки проходят уже как иностранные прямые инвестиции в Россию $^{2}$. В этом случае российские прямые инвестиции равны рыночной стоимости компаний-дочек, а последняя складывается в основном из купленных ими акций российских предприятий. Тогда долларовое обесценение таких российских акций (что и происходит в случае снижения их рублевой рыночной стоимости или девальвации рубля) ведет к переоценке прямых российских инвестиций за рубежом. Масштабы такой переоценки на фоне вполне благополучной ситуации на мировом фондовом рынке в 2014 г. говорят о том, что роль описанной схемы в характере движения российского капитала весьма существенна.

Тогда, с учетом не вполне понятной доли в прямых инвестициях недвижимости, приобретенной российскими резидентами за рубежом, значимость российских прямых инвестиций как источника получения технологий, возможности продвижения отечественной продукции за рубежом, интеграционного потенциала для российской экономики в мировую и т. д. оказывается заметно меньше, чем это представляется на первый взгляд.

${ }^{2}$ Бессмысленный, на первый взгляд, круговорот прямых инвестиций осуществляется главным образом ради снижения налоговых платежей и страховки от рейдерских захватов в России.
Есть, правда, и хорошая новость: масштабы кредитования чужих экономик Российской Федерацией, по-видимому, все же меньше, чем это представляется при некритическом обращении к статистике ЦБ. А плохая - в очередном подтверждении известного факта: чтобы спокойно инвестировать в свою экономику, российский инвестор вынужден прятаться за чужой флаг. Вынуждать своих граждан уходить в чужую юрисдикцию, осознанно или нет, - странная политика с точки зрения самих основ института власти.

Причины вывода капитала за рубеж многообразны. Это возможности снизить налоговые платежи, но не только. Остаются еще «политические» или, если использовать более дипломатичный термин, - институциональные. Специфика российской институциональной системы - предмет самостоятельного рассмотрения [3], здесь же отметим, что с российскими институтами действительно «не все в порядке...». Так, согласно Индексу глобальной конкурентоспособности, Россия по качеству институциональной системы находится на 100-м месте из 144 стран [4]. При таких институтах трудно винить инвестора в том, что он согласен «потерять часть, но сохранить целое», т. е. согласившись на меньшую доходность, существенно, с его точки зрения, сократить риск потери всего капитала, выводя его за рубеж.

Таким образом, низкое качество отечественной промышленной политики и институциональной системы продолжает оставаться серьезной проблемой, препятствующей экономическому развитию РФ.

Портфельные и прочие инвестиции. К этому виду российских зарубежных активов «претензий» еще больше. По сути это чистое кредитование чужих экономик. Возникает вопрос: зачем это делается, особенно в условиях явного недоинвестирования своей? Если абстрагироваться от геополитических соображений (что в современных условиях, правда, едва ли возможно), ответ представляется очевидным. Во-первых, для того чтобы получить прибыль. Во-вторых, чтобы повысить качество инвестиционного портфеля через диверсификацию объектов инвестиций. Очевидность ответа, однако, не означает его истинность.

Действительно, по данным Центробанка РФ, на начало 2014 г. финансовые активы России составили 1474,6 млрд долл., а финансовые обязательства - 1342,9 млрд долл. За этот год 
полученные доходы от инвестиций - 42,2 млрд долл., а выплаченные доходы от них - 100,1 млрд долл. Попытка количественно оценить потери России от существенно различной эффективности российских инвестиций в зарубежные активы и иностранных инвестиций в российские была предпринята в статье Н.П. Дементьева [5]. Здесь же отметим, что в 2014 г. среднюю доходность российских инвестиций за рубежом можно оценить в 2,9\% годовых, а иностранных инвестиций в России $-7,5 \%$ годовых [6]. Бизнес-идея проекта - «вкладываем свои деньги под $2,9 \%$ в чужие экономики и одновременно берем кредит под 7,5\% для инвестиций в свою» (причем вкладываем в остальной мир больше, чем берем у него для российской экономики) - ничего, кроме недоумения, не вызывает.

Аргумент, что эти вложения - гарантия на черный день, также не выдерживает критики. Во-первых, какими бы ни были резервы, столь большая экономика, как российская, долго на них жить все равно не может. Плюс/минус несколько месяцев принципиального значения не имеют. Во-вторых, в условиях санкций и постоянных угроз их расширения зарубежные активы вообще перестали быть гарантией. В любой момент (и вряд ли это будут самые легкие дни для российской экономики) данные активы могут быть даже если и не изъяты, то заморожены на неопределенный срок. Подход, направленный на то, чтобы за счет российской стороны проинвестировать развитие тех стран, которые при легко прогнозируемых обстоятельствах как раз и будут организаторами давления на РФ, никак нельзя считать отвечающим российским интересам.

Гораздо более ответственный подход - инвестировать российские деньги в свою экономику, что, в отличие от сложившейся практики, как раз и является если не гарантией, то все же значимым шагом в направлении, отдаляющим, а не приближающим, как в настоящее время, наступление черного дня.

А инвестировать есть что. Действительно, на 1 апреля 2015 г. величина прочих инвестиций за рубежом составила почти 0,4 трлн долл. В основном это наличная валюта и депозиты (170 млрд долл.), ссуды и займы (164 млрд долл.), торговые кредиты и авансы и прочая дебиторская задолженность (56 млрд долл.). Напомним, что в основной капитал по производству машин и оборудования (без учета оружия и боеприпасов) в 2014 г. было инвестировано 99,8 млрд руб. (по среднегодовому курсу 2014 г. 37,97 руб./долл. - 2,6 млрд долл.). То есть на кредитование чужих производителей, в том числе машиностроителей, было направлено в 22 раза больше средств, чем на своих. Впрочем, что говорить о машиностроении! Инвестиции во всю отечественную обрабатывающую промышленность в 2014 г. были меньше, чем величина российских средств, предоставленных зарубежным контрагентам в качестве торговых кредитов, авансов и прочей дебиторской задолженности.

Еще сильнее обескураживает соотношение величины ссуд и займов, предоставленных российскими резидентами остальному миру, и инвестициями в отечественную экономику. Так, первая величина (164 млрд долл.) примерно соответствовала объему инвестиций 2014 г. в основной капитал сельского хозяйства, добывающей и обрабатывающей промышленности, производства и распределения электроэнергии, газа и воды, образования и здравоохранения вместе взятых.

Понятно, что ссуды и займы, предоставленные нерезидентам, приносят определенный доход (как показано выше, не слишком большой). Очевидно, что в какой-то степени они способствуют и продвижению отечественной продукции на зарубежные рынки. Однако извечное стремление капитала к получению прибыли здесь явно вступает в противоречие с национальными интересами. Последние требуют осуществления инвестиций в национальную экономику. В этом случае инвестор не только получит прибыль, большую, чем ту, на которую он может рассчитывать за рубежом, но и решит целый комплекс социальных задач. Будут созданы рабочие места, усилится национальная производственная система, сформируется поток налогов (НДС, налог на прибыль, страховые платежи, налог на имущество и др.), которые пойдут на развитие отечественной, а не чужой экономики.

А ведь помимо 0,4 трлн долл. прочих инвестиций почти столько же - 356 млрд долл. - аккумулировано в резервных активах (ценные бумаги - 254 млрд, наличная валюта - 44 млрд, монетарное золото - 47 млрд и др.). Особое недоумение вызывает статья «ценные бумаги». Это в основном ценные бумаги правительств ведущих стран Евросоюза и США. По данным Банка России, на 31.12.2014 г. структура географического распределения его валютных активов выглядела следующим образом: 
Франция - 33,2\%, США - 24,7\%, Германия - 16,1\%, Соединенное Королевство - 9,3\%, прочие страны - 16,7\%. В январе-декабре 2014 г. доходность валютных активов Банка России, номинированных в долларах и евро, составила соответственно $0,13 \%$ и $0,39 \%$ годовых.

Хранить по меньшей мере четыре годовых инвестиционных бюджета всей обрабатывающей промышленности РФ 2014 г. в бумагах наших не слишком надежных друзей, практически не приносящих ни дохода, ни дающих особых гарантий по использованию данных средств в критический для РФ момент, - это удивительно!

Справедливости ради следует отметить, что страсть российских финансовых органов к приобретению иностранных ценных бумаг все же пошла на убыль. Если на начало 2005 г. РФ располагала долгосрочными иностранными бумагами на сумму в 13 млрд долл., в 2013 г. - уже на 355,7 млрд долл., то на начало второго квартала 2015 г. их осталось «только» на сумму 220 млрд долл.

Нельзя не отметить, что уменьшение кредитования Россией чужих экономик в последние полтора года, к сожалению, не привело к увеличению инвестиций в свою. Возможно, впрочем, это все же в какой-то степени способствовало предотвращению серьезного внутреннего инвестиционного спада.

\section{Иностранные активы в России}

Обязательства РФ перед остальным миром, как и ее активы в этом мире, за полтора десятилетия прошли большой путь. На конец 2000 г. они составляли 184,2 млрд долл., к началу 2014 г. достигли своего пика - 1,3 трлн долл., а к 2015 г. снизились до 946 млрд долл. В 2015 г. тренд на снижение обязательств продолжился. Следует отметить, что этот процесс был следствием не столько операций (выхода иностранных резидентов из российских активов), сколько их переоценки.

Иностранные активы в РФ примерно на 2/3 состоят из прямых и портфельных инвестиций нерезидентов (долговые ценные бумаги, участие в капитале и акции инвестиционных фондов), ссуд и займов (примерно 1/5, в основном долгосрочные небанковского сектора); остальное приходится на товарные кредиты и авансы, кредиторскую задолженность и специальные права заимствования.

Различия российских активов и обязательств, таким образом, в том, что в структуре обязательств нет низкодоходных резервных активов, что отчасти и предопределяет существенное различие в эффективности российских инвестиций в зарубежные активы и иностранных инвестиций в российские, обсуждавшееся выше. Мы уже говорили о нулевой доходности российских валютных резервов, но довольно низка доходность и прочих российских активов. Если отнести величину российских инвестиционных доходов, получаемых за рубежом, к общему объему российских зарубежных активов, за вычетом резервных, их эффективность для 2014 г. не превысит 4,4\% (напомним, что эффективность зарубежных активов в РФ 7,5\%). Таким образом, при любом способе расчетов вложения в российскую экономику выгоднее, чем в зарубежную. Тем более вызывающе выглядит стремление российских резидентов вывести свои капиталы за рубеж.

Тем не менее утверждать, что инвестирование в Россию эффективная стратегия, можно лишь с рядом существенных оговорок. Россия - высокорискованный объект для инвестиций. Так, до 2007 г. инвестиции в РФ были чрезвычайно выгодны как с точки зрения дохода на вложенный капитал, так и, что часто остается в тени, роста стоимости активов. Действительно, только с 2001 по 2007 гг. стоимость иностранных активов в РФ по результатам переоценок повысилась на 609 млрд долл. Правда, в 2008 г. они подешевели на 582 млрд долл. В 2009-2010 гг. ситуация вновь улучшилась. Затем для иностранных инвесторов в РФ наступили тяжелые времена (рис. 6).

За рассмотренный период совокупные потери иностранных инвесторов в России с учетом отрицательных результатов по переоценке активов и положительных по прочим изменениям составили 31 млрд долл., а российских инвесторов за рубежом почти 0,5 трлн долл. (см. табл. 1). Поневоле возникает вопрос: «Если российские резиденты столь неэффективны в своих инвестициях за рубежом, может, пора их как-то ограничить?». Во всяком случае, до тех пор, пока они не начнут демонстрировать более адекватные результаты. 


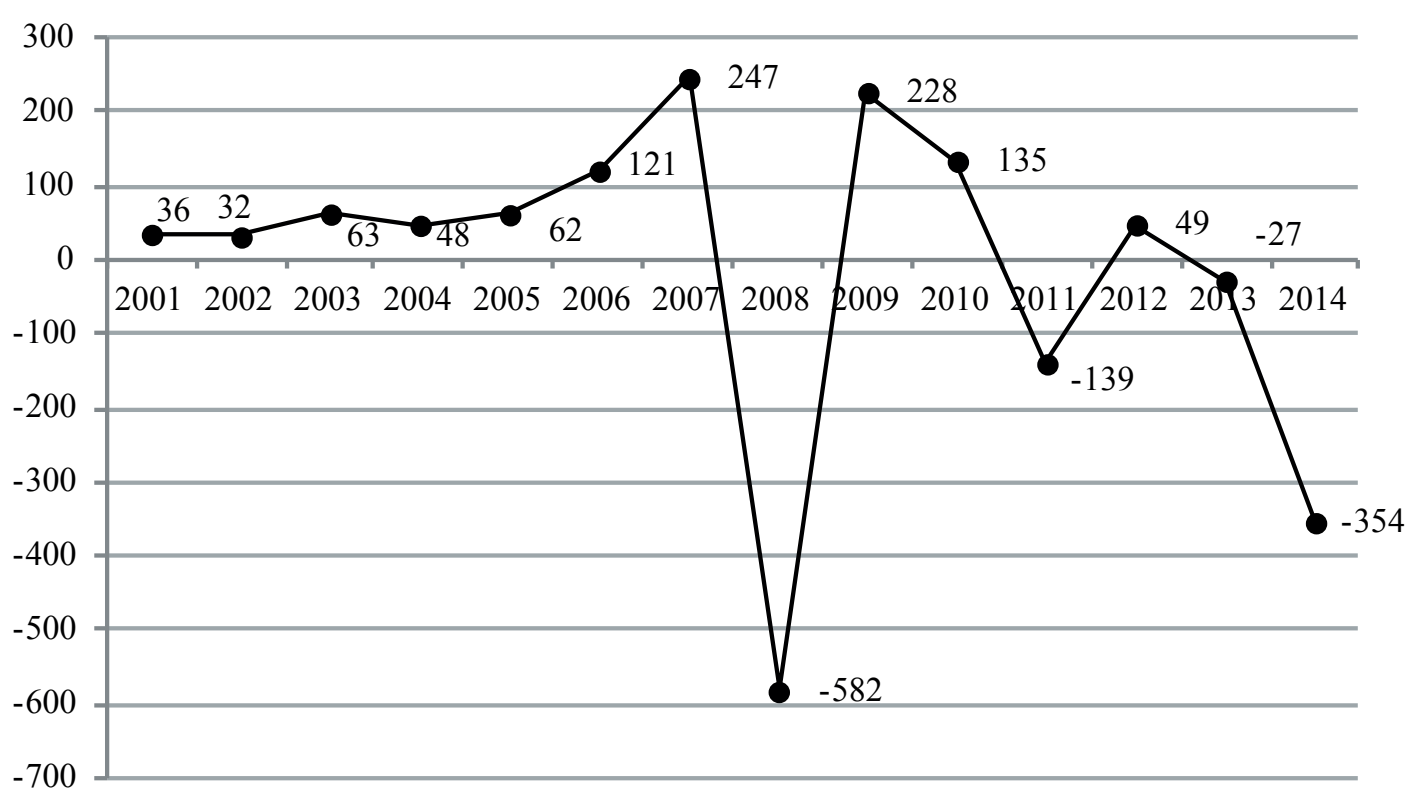

Источник: ЦБ РФ. Статистика внешнего сектора. URL: http://www.cbr.ru/statistics/? Prtld=svs (дата обращения: 09.10.2015).

Рис. 6. Изменение стоимости иностранных активов в РФ в результате переоценки в 2001-2014 гг., млрд долл.

\section{Россия - кредитор мировой экономики}

Баланс активов и обязательств весьма показателен: в 20002004 гг. он положителен, но при этом быстро уменьшается. В 2005-2008 гг. чистая международная инвестиционная позиция (ЧМИП) РФ и вовсе становится отрицательной. Кажется, вот оно - свершилось! Российская экономика стала настолько привлекательной, что капитал устремился в Россию, а не из нее, как было до сих пор. Но не стоит спешить с выводами.

Действительно, смена качества (дебитор - кредитор) - вовсе не достижение проводимой экономической политики. Дело в том, что в рассматриваемый период иностранные активы в РФ увеличивались, но в большей части это определялось ростом рублевой стоимости акций, поддерживаемым реальным укреплением рубля. Для российских активов за рубежом этот эффект был существенно слабее, причем фактор изменения реальной стоимости национальной валюты отсутствовал.

Финансовый кризис 2008-2009 гг. расставил все по своим местам: чистая международная инвестиционная позиция РФ вновь стала положительной. Россия вернулась к статусу нетто-кредитора остального мира. Резкое изменение ЧМИП при изменении экономической конъюнктуры объясняется большей частью тем, что структуры внешних активов России и ее финансовых обязательств существенно асимметричны. В начале 2008 г. на прямые инвестиции и долевые ценные бумаги в составе портфельных инвестиций приходилось 34\% всех внешних активов России, тогда те же финансовые инструменты составляли $64 \%$ ее внешних финансовых обязательств. Между тем львиная доля переоценок всех активов и обязательств приходится, как правило, на прямые инвестиции и долевые ценные бумаги в составе портфельных инвестиций.

В начале нынешнего мирового кризиса резко снизилась рыночная стоимость акций как российских, так и зарубежных корпораций. Но из-за асимметрии структур российские активы снизились намного меньше, чем ее финансовые обязательства Этому же способствовала и резкая девальвация рубля, вследствие чего долларовая оценка российских акций (номинированных в рублях), находящихся у нерезидентов, уменьшилась.

Аналогичный эффект наблюдался в 2014-2015 гг. Здесь он, однако, был дополнен снижением объема займов и ссуд, взятых российскими резидентами у их зарубежных визави. Это снижение, следует отметить, в значительной степени стало возможным благодаря уменьшению резервных активов (в первую очередь долгосрочных ценных бумаг).

Все эти годы в РФ активно обсуждаются проблема дефицита капитала, слабость отечественной банковской системы, не желающей финансировать масштабные инвестиционные проекты с более или менее длительными сроками окупаемости, скудные собственные финансовые возможности потенциальных инвесторов. В то же время РФ продолжает кредитовать чужие экономики в масштабах, сопоставимых с инвестициями в свою. Действительно, ЧМИП РФ на начало 2015 г. составила 310 млрд долл. В основной же капитал в 2014 г. в РФ было инвестировано 356,3 млрд долл. Понятно, что прямое сопоставление этих величин некорректно, тем не менее если условно направить эти 310 млрд долл. на инвестиции, инвестиционная программа возрастает почти вдвое. При этом ни о каком возрастании долговой нагрузки на российскую экономику речь не идет. Просто в данном гипотетическом случае РФ становится должна остальному миру ровно столько, сколько остальной мир должен РФ (табл. 2). 


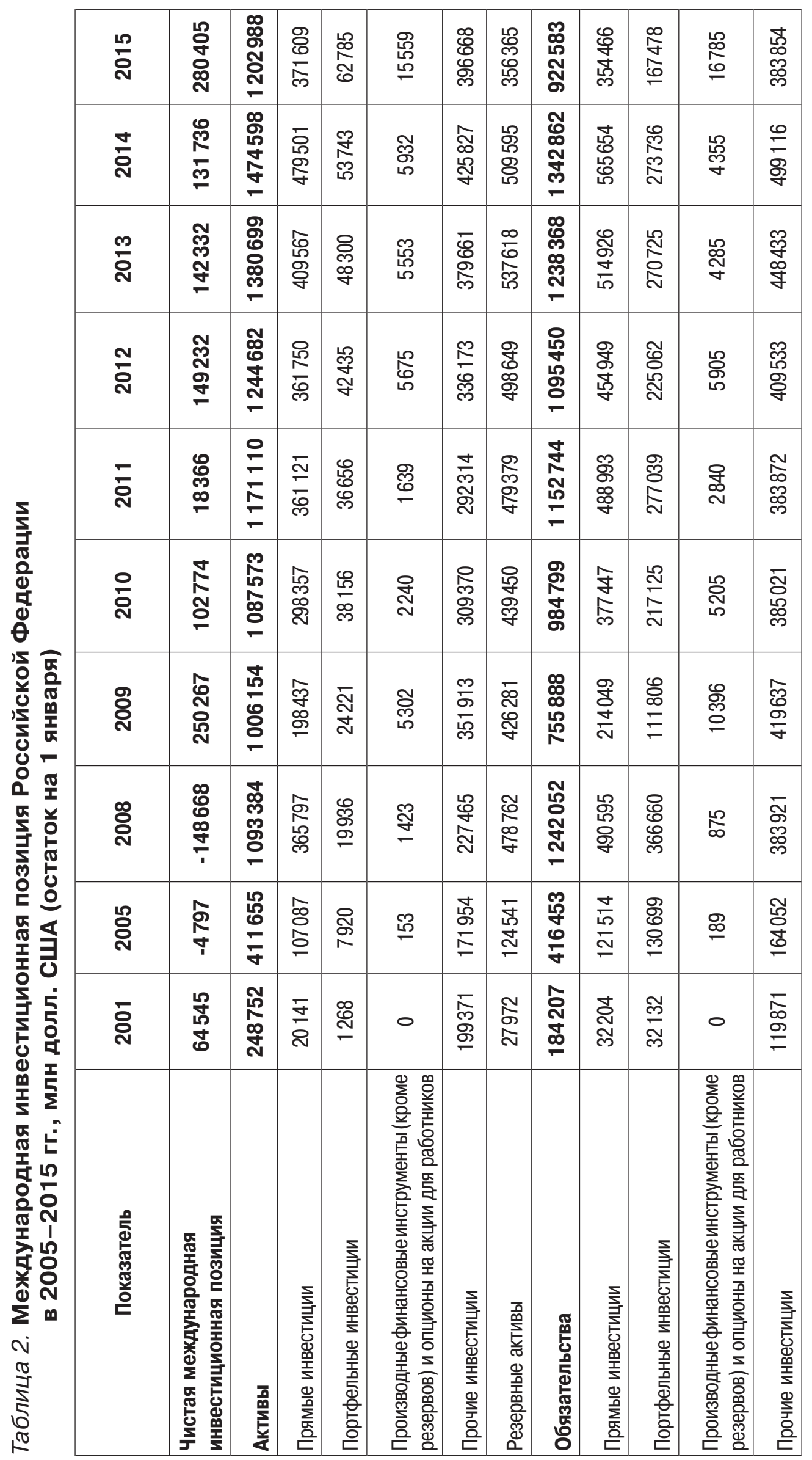

В условиях, когда РФ масштабно относительно размеров своей экономики кредитует остальной мир, странно воспринимаются разговоры о том, что мы, находясь под санкциями, «поражень в правах» в привлечении капитала для финансирования экономики в целом и инвестиционных программ, в частности. Так, если предпринимателю по каким-либо причинам не дают кредит в банке, но при этом он кредитует всех желающих в масштабах, больших, чем кредит, на который он претендует, то это вызывает, мягко говоря, «когнитивный диссонанс». На уровне же государства в целом данная ситуация воспринимается как совершенно нормальное явление. Невольно вспоминается классическое «Может, что-то в консерватории подправить?».

Проблема не в том, что зарубежные контрагенты перестали давать деньги на развитие нашей экономики (и это обстоятельство как бы является оправданием не слишком блестящих отечественных достижений последних лет). «По гамбургскому счету» ничего не изменилось. Просто в дискуссиях о свободном перемещении капитала всегда в тени оставался факт, что в российскую экономику капитал систематически перемещался в менышем количестве, чем из нее, т. е. что на протяжении многих лет Россия является нетто-кредитором остального мира. Причем в последнее время эта тенденция только усиливается.

Необходимо разобраться с причинами, вынуждающими российских инвесторов уходить в чужие юрисдикции [7]. Это сложнее, чем обвинять в наших трудностях определенные круги в США и их европейских сателлитов, но сделать придется. Строго говоря, ухудшившиеся внешние условия - прекрасная возможность интенсифицировать решение давно назревших проблем.

\section{Литература}

1. Федеральная служба государственной статистики [Электронный реcypc]. URL: www.gks.ru

2. Академик. Словари и энциклопедии [Электронный ресурс]. URL: http:// dic.academic.ru/dic.nsf/ruwiki/674717

3. Алексеев А. В. Приоритеты государственной политики создания инновационной экономики в РФ / ИЭОПП СО РАН. - Новосибирск, 2015. - 423 с. 4. The Global Competitiveness Report 2015-2016. - P. 306.

5. Дементьев Н.П. Проблемы доходности внешнего сектора экономики России // ЭКО. - 2014. - № 11. - С. 168-183.

6. ЦБ РФ. Статистика внешнего сектора [Электронный ресурc]. URL http://www.cbr.ru>statistics/? Prtld=svs

7. Клисторин В.И. Поверхностная диагностика - сомнительное лечение // ЭКО - 2014 - № 11. - С. 184-186. 